Canadian University Music Review

Revue de musique des universités canadiennes

\title{
Apropos Aesthetic Autonomy
}

\section{Friedemann Sallis}

Volume 24, numéro 1, 2003

URI : https://id.erudit.org/iderudit/1014668ar

DOI : https://doi.org/10.7202/1014668ar

Aller au sommaire du numéro

\section{Éditeur(s)}

Canadian University Music Society / Société de musique des universités canadiennes

\section{ISSN}

0710-0353 (imprimé)

2291-2436 (numérique)

Découvrir la revue

\section{Citer ce document}

Sallis, F. (2003). Apropos Aesthetic Autonomy. Canadian University Music Review / Revue de musique des universités canadiennes, 24(1), 1-6. https://doi.org/10.7202/1014668ar
Résumé de l'article

La présente contribution au Débat critique des prises de position problématiques, apparues depuis quelques années dans les pages de cette revue, concernant la notion d'autonomie esthétique dans le domaine musical. Le ton est franc, l'intention est constructive et le but est de susciter un échange d'idées avec des collègues dont les points de vue sur ces questions peuvent différer.
All Rights Reserved (C Canadian University Music Society / Société de musique des universités canadiennes, 2005
Ce document est protégé par la loi sur le droit d'auteur. L'utilisation des services d'Érudit (y compris la reproduction) est assujettie à sa politique d'utilisation que vous pouvez consulter en ligne.

https://apropos.erudit.org/fr/usagers/politique-dutilisation/ 


\title{
COLLOQUY/DÉBAT: APROPOS AESTHETIC AUTONOMY
}

\author{
Friedemann Sallis
}

Over the past decade, the notion of aesthetic autonomy has come under attack. Evidence of this is abundantly present in recent articles of our Review, where we read that the "dangerous" illusion of autonomy in the arts and sciences (Beverley Diamond, in Shepherd and Diamond 1998, 17) has been successfully challenged by American ethnomusicologists and popular music specialists (John Shepherd, in Shepherd and Diamond 1998, 10). According to David Gramit, we find ourselves in this state of affairs because of musicology's consistent failure to link its object of study (the self-contained, autonomous work of Western art music) to broader political and cultural concerns (Gramit 1998, 20).

Before going any further, I would like to clearly state that this letter is not a call for a return to older practices, where musicology was often reduced to middle-aged gentlemen comfortably chatting about their favourite bits of the canon over a glass of sherry at the local faculty club. In my view, good musicology has always been and should remain a "bright, multicoloured, multicultural world" (Shepherd, in Shepherd and Diamond 1998, 10), in which all approaches to the study of music (be they formalist, hermeneutic, aesthetic, historic, socio-economic, cultural, etc.) can be compared and criticized. It is worth noting however that there is nothing new here. Marxist-oriented historians such as Lucien Febvre and Marc Bloch, who founded the Annales d'histoire économique et sociale in 1929, postulated that anything can be part of historical discourse. At about the same time Max Weber's truly pioneering essay, The Rational and Social Foundations of Music, was published posthumously ${ }^{1}$ and Theodor Adorno began working towards his sociology of music. ${ }^{2}$ Also, I see no problem in examining the ideological underpinnings of all approaches to the study of music, which, as Gramit $(1998,20)$ has correctly pointed out, may "intentionally or inadvertently limit the object of musicological inquiry in a way that excludes from the start much of what could fall within the scope of the discipline." Having said that, I believe we should heed Carmen Sabourin's warning against entering all too quickly into that "supermarché de la pensée," which has sprung up over the past decade $(1997,113)$. Take for example

I Though written in 1911, the work was not published until a year after the author's death (Weber 1921)

2 Adorno published his article, "On the Social Situation of Music," in two instalments (1932a, 1932b). 
Lawrence Kramer's attempt to ground a radically new musicology (which I would add in passing explicitly rejects the notion of aesthetic autonomy). In a scant few pages Kramer blithely skips through the ideas of Carl Dahlhaus, Jacques Derrida, Jacques Lacan and Julia Kristeva, with Jean-François Lyotard lurking unacknowledged behind the scene (Kramer 1996, 16-21). This kind of "drive-thru" musicology is superficial in the extreme and should be criticised as such. (The disclaimer that this brand of musicology revels intuitively in the hic et nunc in order to get beyond the aporia of modernist musicology is simply disingenuous.)

In the following, I would like to bring up a few points concerning aesthetic autonomy, which appear to have been neglected in recent writings on the subject.

1. It is ironic that those who benefit most from the concept of aesthetic autonomy should be attacking it so vigorously. The ability to read new and different meanings into musical experience, which seems to be the motivating factor behind a great deal of today's musicology, is historically dependent on the development of the category of the isolated, self-contained work, which, for Walter Benjamin at least $(1998,55)$, remained the "supreme reality of art". This category was developed hand in hand with the idea that a musical work is a text to be interpreted, rather than simply a recipe for performance. ${ }^{3}$ Many of the various tools and methodologies we now have at our disposal for the study of music were conceived during the nineteenth-century as composers and critics attempted to come to terms with the musical composition as a work of art. Also it is supercilious to complain about a "German groove," in which certain types of musicology appear to be stuck (Shepherd, in Shepherd and Diamond 1998, 6). One could just as easily complain about British, French and American grooves; though we ought to be generous enough to admit that no group has a monopoly on either genius or mediocrity. To be sure, the academic study of music has changed a great deal and will no doubt continue to do so. Criticising our predecessors for not being able to jump over their own shadows is however a cheap rhetorical trick.

2. Even Lawrence Kramer (1996, 16-17) admits that the notion of aesthetic autonomy can no longer be considered an absolute principle, if it ever was in the first place. To quote Dahlhaus directly: "Nowadays [ca. 1975] no-one even remotely familiar with the discussion of aesthetic autonomy would dispute the proposition that it is not a principle divorced from and lording over history so much as a phenomenon that has historical limitations and is subject to historical change" $(1982,108)$. The young Romantics themselves saw the autonomous work, not as an end in itself, but rather as a means by which one could attain the sublime. ${ }^{4}$ Thus, on the one hand, the suggestion that such a historically contingent phenomenon should be seen as "dangerous" seems to me to be

3For an excellent discussion of this point see Goehr 2002.

4 See for instance, Novalis's insistence that the best initiation to the new (Romantic) philosophy was through an expressive performance of Mozart's An Chloe K542. Friedrich Hardenburg (alias Novalis), "Vorarbeiten zu verschiedenen Fragmentsammlungen" (1798), cited in Frank (1989, 221). 
overstating the case. On the other, we might also be mindful of the dangers involved in overextending the social imperative. Prescriptive statements like, "Music is of this world, and should be examined as such" (Shepherd, in Shepherd and Diamond 1998,11), carry with them the memory of the malicious abuse of both composers and academics, which unfortunately litters our recent history. Just over fifty years ago Andrei Zhdanov launched his tirade against formalism and elitism in music at the All Union Congress of Soviet Composers (Moscow 1948). He finished his address with the sinister admonition that "not only the musical, but also the political ear of Soviet composers must be very keen" (Zhdanov 1950, 96). Not a few people, both in the East and the West, took this position to be self-evident. Of course, I am convinced that neither Diamond nor Shepherd subscribe to or condone this kind of abuse. Nonetheless, in our rush to "reinvent culture" (Diamond, in Shepherd and Diamond $1998,15)$, we would do well not to forget the lessons of the past.

3. Many of those who do "new" musicology like to think of themselves as taking the ethically high road. They stand up for the musicologically downtrodden. Witness Susan Fast's suggestion that musicologists refrain from using musical examples in their writings so as not to "alienate" musical illiterates (Fast 2000, 50). As an alternative she points to Robert Walser's bar by bar description of a Van Halen song, "Running with the Devil." As presented by Fast, Walser's verbosity reminds me of renderings of Tchaikovsky's 1812 Overture, which we used to call music appreciation. Such "record jacket" narratives were and presumably still are meant as explanations for those too dull to "get it" on their own. They are at once intellectually redundant and socially distasteful, in that they present an image of the university professor stooping to provide his or her considered opinion to the uncomprehending masses. Fans do not need musicologists telling them what to listen to. Even if they may be incapable of articulating their ideas of this music, they know what they like. That is after all why they spend their money on these products. Be that as it may, Fast's approach resonates well with Kramer's project to save classical music for the broad American public. This is to be done through concentration on the immediacy of the "music itself," entailing a kind of listening that attempts to get beyond the bounds of the fetishised work of art (Kramer 1996, 18-19). He defines this sort of musical experience by asking rhetorically: "Am I failing to experience the music when I vary my attention level or simply let it fluctuate, when I interrupt a sound recording to replay a movement or a passage, when I find myself enthralled by a fragment of a piece that I hear on my car radio...?" (65). In other words, we must pay for wider public acceptance by transforming the musical art of the past into a kind of generalised "musak," pliable enough for even the shortest attention span. Pieter van den Toorn has noted with resignation that the study and appreciation of Western art music risks becoming elitist (Toorn 1995, 4). He is mistaken. It has never been anything else. From the chanson française of the fourteenth and fifteenth centuries (conceived at a time when the notion of aesthetic autonomy as we understand it did not yet exist) to György Ligeti's Horn Trio, this music 
has always been the domain of the happy few, and will no doubt remain so for the rest of our careers. Though it may offend our democratic sensitivities, this social fact can not simply be wished away. Indeed, this also appears to be the case with other non-Western, elitist music traditions, which, like ours, demand initiation (i.e. willingness and an ability to invest time and intellect in an attempt to understand something, which, at first blush, may appear difficult). If, as the culture specialists remind us again and again, these types of music document hierarchy and oppression based on race, class and/or gender (Finn 1997; Leppert 1998, 302-5), they also constitute some of humanity's most extraordinary achievements.

4. At this point, some readers might expect concluding remarks on the enduring value of the classical canon "as it is now and ever shall be, world without end, amen!" They will be disappointed. Like galaxies in the night sky, the music of Monteverdi, Bach, Mozart, Chopin, et al. is slowly but surely drifting away from us. One day it will sound just as marvellously strange as the bilingual motets of the thirteenth century do today. Neither Kramer's overarching imagination, nor the illusions of many of those involved in authentic performance practice, nor even our apparently unlimited ability to record, stock, and access all sound will change this state of affairs, and rightly so. Our culture's capacity to leave behind part of itself is essential because it provides aesthetic space within which the composers of today and tomorrow will develop their talent. ${ }^{5}$ Throughout the past century and despite enormous problems, composers from Erik Satie to Toru Takemitsu have continued to enrich and expand the concept of Western art music. They have been able to do this in part because the category of the autonomous, self-contained work of art remains a viable part of our culture. Of course, the concept of aesthetic autonomy is, to paraphrase Adorno, historic through and through. It has and will continue to change, and may well disappear entirely one day. ${ }^{6}$ In the meantime, I am pleased to report that Canadian composers such as Chantal Laplante, James Harley and many others seem intent on working within this rich frame of reference well into the present century. ${ }^{7}$

Over the past one hundred years, Western art music has shown itself to be remarkably resilient. Tomorrow, many composers will no doubt seek rapid gratification in the grey conformity of the international mass-media marketplace. Others like Giacinto Scelsi, Helmut Lachenmann and Galina Ustvol'skaja, will shun it and attempt to go another way. Some, like Robert

5For more on this point see Sallis 1997.

6Eric Hobsbawm $(1995,519)$ asserts for instance that by the middle of the twentieth century, Western art had become "essentially cooperative rather than individual, technological rather than manual... The talents that went into the characteristic forms of twentieth-century creation, which were mainly products for, or by-products of the mass market, were not inferior to those of the classic nineteenth-century bourgeois model, but they could no longer afford the classical artist's role of the loner."

7Laplante and Harley are mentioned here because, shortly before writing this piece, I had the opportunity to hear their music at the annual meeting of the Canadian University Music Society held at Lennoxville in June 1999. Hundreds of other names could have been mentioned. 
Ashley and John Zorn will seek to redeem aspects of this stultifying environment by incorporating parts of it in their work. The latter approach represents not only an example of cultural rejuvenation, but also of cultural continuity. The redemption of life through art was precisely one of the principal justifications for the aesthetically autonomous work of musical art as the young Romantics defined it some two hundred years ago.

\section{REFERENCE LIST}

Adorno, Theodor. 1932a. "Zur gesellschaftlichen Lage der Musik." Zeitschrift für Sozialforschung 1/2: 103-24. First instalment.

1932b. "Zur gesellschaftlichen Lage der Musik." Zeitschrift für Sozialforschung 1/3: 356-78. Second instalment.

Benjamin, Walter. 1998. The Origin of German Tragic Drama. London: Verso. Dahlhaus, Carl. 1982. Foundations of Music History. Cambridge: Cambridge University Press.

Fast, Susan. 2000. "Same As It ever Was? Musicology Continues to Wrestle with Rock." Canadian University Music Review, no. 21/1: 40-53.

Finn, Geraldine. 1997. "White Noise: Composition, Colonization, and Colour." Canadian University Music Review, no. 18/1: 66-83.

Frank, Manfred. 1989. Einführung in die frühromatische Ästhetik. Frankfurt/M: Suhrkamp.

Goehr, Lydia. 2002. The Imaginary Museum of Musical Works. An Essay in the Philosophy of Music. Oxford: Oxford University Press.

Gramit, David. 1998. "The Roaring Lion: Critical Musicology, the Aesthetic Experience, and the Music Department." Canadian University Music Review, no. 19/1: 5-33.

Hobsbawm, Eric. 1995. Age of Extremes. The Short Twentieth-Century 19141991. London: Abacus.

Kramer, Lawrence. 1996. Classical Music and Postmodern Knowledge. Berkeley: University of California Press.

Leppert, Richard. 1998. "Desire, Power and the Sonoric Landscape: Early Modernism and the Politics of Musical Privacy." In The Place of Music, eds. Andrew Leyshon, David Matless, and George Revill, 302-5. New York: Guilford Press.

Sabourin, Carmen. 1997. "La critique féministe étasunienne en musique : pertinence en milieu francophone québécois." Canadian University Music Review, no. 18/1: 99-118.

Sallis, Friedemann. 1997. "La transformation d'un héritage: Bagatelle op. 6 $\mathrm{n}^{\mathrm{o}} 2$ de Béla Bartók et Invenció (1948) de György Ligeti." Revue de Musicologie 83, no. 2: 281-93.

Shepherd, John, and Beverley Diamond. 1998. "Colloquy/Débat: Theory and Fieldwork." Canadian University Music Review, no. 19/1: 4-18.

Toorn, Pieter C. van den. 1995. Music, Politics and the Academy. Berkeley: University of California Press. 
Weber, Max. 1921. Die rationalen und sozialen Grundlagen der Musik. Tübingen: J.C.B. Mohr.

Zhdanov, Andrei A. 1950. Essays on Literature, Philosophy and Music. New York: International Publishers.

\begin{abstract}
The present contribution to the Colloquy takes issue with problematic positions on aesthetic autonomy in music, which have appeared over the past couple of years in the pages of this journal. The tone is frank, the intention is constructive and the point is to engage in an exchange of ideas with colleagues who may have different points of view on these matters.
\end{abstract}

\title{
Résumé
}

La présente contribution au Débat critique des prises de position problématiques, apparues depuis quelques années dans les pages de cette revue, concernant la notion d'autonomie esthétique dans le domaine musical. Le ton est franc, l'intention est constructive et le but est de susciter un échange d'idées avec des collègues dont les points de vue sur ces questions peuvent différer. 